Ewa Bujwid-Kurek

\title{
Kosowscy entuzjaści contra kosowscy sceptycy. Dyferencjacja państw wobec legalności Republiki Kosowa
}

Kosowo, będące pokrainą Republiki Serbii, ogłosiło jednostronny akt niepodległości 17 lutego 2008 r. Od tego momentu, a właściwie już nieco wcześniej, obserwuje się wyraźny podział państw, w tym także członków Unii Europejskiej (UE), na te, które niemal od pierwszego momentu w pełni zaakceptowały samodzielność Kosowa, jak i te, które do chwili obecnej wciąż jeszcze nie mogą zgodzić się z zaistniałym stanem rzeczy.

Przypomnijmy, że w Kosowie, które zamieszkiwała ludność w większości etnicznie albańska, wyznająca islam, ruch niepodległościowy eskalował, począwszy od śmierci „ojca narodów” - Josipa Broz-Tity, tj. od 1980 r. ${ }^{1} 27$ lutego 1989 r. władze serbskie wprowadziły w Kosowie stan wyjątkowy, a wkrótce aresztowały byłego przywódce partii komunistycznej w Kosowie - Albańczyka Azema Vllasiego. Wydarzenia te przyczyniły się do wybuchu kolejnych zamieszek w marcu jeszcze tego samego roku, w wyniku których zginęło 20 osób. Przypomnieć też trzeba, że 23 marca 1989 r. władze Serbii

${ }^{1}$ W 1997 r. uaktywniła się partyzancka grupa zbrojna Wyzwoleńcza Armia Kosowa (UÇK) i przeprowadziła ataki na serbskie siły bezpieczeństwa $\mathrm{w}$ prowincji, powodujace represje prowadzone $\mathrm{z}$ rozkazu serbskiego przywódcy Slobodana Miloševicia, J.S. Nye, Konflikty międzynarodowe. Wprowadzenie do teorii i historii, tł. M. Madej, Warszawa 2009, s. 238. 
zniosły, przyznany w 1970 r., potwierdzony zapisem Konstytucji Socjalistycznej Federacyjnej Republiki Jugosławii (SFRJ) z 22 lutego 1974 r., status autonomiczny Kosowa. Kosowo i Wojwodina zostały włączone bezpośrednio do Republiki Serbii. W tym samym czasie wojsko serbskie brutalnie stłumiło protesty kosowskich Albańczyków². W lipcu 1989 r., zgodnie z nową Konstytucją Republiki Serbii, jeszcze będącej podmiotem SFRJ, doszło do likwidacji albańskich instytucji politycznych. W odpowiedzi - w lipcu 1990 r. Albańczycy z Kosowa ogłosili „pierwszą" deklarację niepodległości, jednocześnie powołując rząd podziemny, którego premierem został dr Bujar Bukoshi ${ }^{3}$.

Za główny cel badawczy przyjęto tu ustalenie przesłanek, które legły u podstaw uznania Republiki Kosowa jako samodzielnego państwa przez te kraje, które autorka zalicza do grona kosowskich entuzjastów, jak też wskazanie na powody, którymi kierują się inne, nazwane przez autorkę kosowskimi sceptykami.

Uznanie konkretnego państwa przez inne decyduje o tym, że dany podmiot (czytaj: państwo) dopiero odtąd zaczyna w pełni korzystać ze swojej podmiotowości w prawie międzynarodowym. Tak się zwykle dzieje, chociaż z doktryny wynika pogląd, że nie jest to wymóg sine qua non dla ustalenia suwerennego bytu państwowego. Stąd nie bez znaczenia jest, by z niebywała precyzją przestrzegać momentu uznania państwa, ażeby nie zaistniało niebezpieczeństwo przedwczesnej

${ }^{2}$ S. Wojciechowski, Konflikt w Kosowie, [w:] Spory i konflikty międzynarodowe. Aspekty prawne i polityczne, pod red. W. Malendowskiego, Warszawa 2000, s. 366.

${ }^{3}$ F. Gołembski, Etniczne podtoże konfliktów na terenie byłej Jugostawii, [w:] Nacjonalizm. Konflikty narodowościowe w Europie Środkowej $i$ Wschodniej, pod red. S. Helnarskiego, Torun 1994, s. 335. Patrz też S. Wojciechowski, op. cit., s. 354. 
decyzji w tej kwestii. Takie bowiem uznanie może być m.in. powodem do oskarżeń o ingerencję $\mathrm{w}$ wewnętrzne sprawy suwerennego podmiotu prawa międzynarodowego.

Wśród państw-członków Unii Europejskiej tylko pięć państw wciąż nie uznaje samodzielnego Kosowa. UE pozostawia swoim członkom prawo do wyłącznej decyzji, co do jego uznania (bądź nie). Wśród tych państw unijnych, które wydają się być jednoznacznie zdeterminowane w nieuznawaniu, sa: Hiszpania, Cypr, Grecja, Rumunia i Słowacja ${ }^{4}$. Pozostałe 23 bardzo szybko zgodziły się na proklamowanie niepodległości przez Kosowo ${ }^{5}$. Z krajów pozaunijnych nie akceptują tego jednostronnie ogłoszonego aktu niepodległości np. Republika Serbii, a z państw spoza kręgu pojugosłowiańskiego - Federacja Rosyjska i Chińska Republika Ludowa.

$\mathrm{W}$ tym miejscu nasuwają się przynajmniej dwa zasadnicze pytania badawcze. Pierwsze: Czy wymienione państwa, niechętne Kosowu, wyróżniają się jakąś specyficzną wspólną cechą? Drugie: Co może w przyszłości spowodować niejednolitość opinii co do statusu Kosowa wśród państw nie tylko tworzących UE?

Po ogłoszeniu niepodległości przez Kosowo niemal natychmiast zareagował rząd Republiki Serbii, zaniepokojony uznaniem tego aktu przez niektóre państwa. Za pośrednictwem ówczesnego szefa dyplomacji, Vuka Jeremicia, wystapił

${ }^{4}$ Unia Europejska skierowała do Kosowa swą największą misję cywilną EULEX Kosowo. Zakładano, że będzie ona liczyć 1800 osób personelu międzynarodowego i 1200 pracowników lokalnych. W skład tej misji wchodzą także funkcjonariusze policji, obsługujący wymiar sprawiedliwości, personel administracyjny oraz celnicy, Po dwóch latach Kosowo wciaż dzieli kraje UE, http://www.euractiv.pl/polityka-zagadnienia/artykul/po-dwoch-latach-kosowo-wci-dzieli-kraje (dostęp 8 III 2013).

${ }^{5}$ Zob. http//www.politykaglobalna.pl/2010/09/uznac-abchazje-i-osetie-poludnowa (dostęp 8 III 2013). 
15 sierpnia 2008 r. do Zgromadzenia Ogólnego ONZ o przekazanie Międzynarodowemu Trybunałowi Sprawiedliwości (MTS) wniosku o zbadanie kwestii legalności kosowskiej deklaracji niepodległości. Jeremić pytał: Czy jednostronna deklaracja niepodległości, ogłoszona przez tymczasowe władze samorzqdu kosowskiego, jest zgodna $z$ prawem międzynarodowym? ${ }^{6}$ Gdyby pytać o to, czy secesja jest zgodna z prawem międzynarodowym, to $\mathrm{w}$ zasadzie nie znajdziemy jednoznacznej odpowiedzi, bynajmniej nie precyzuje jej orzecznictwo MTS. Pewne jest jednak, że prawo do legalnej secesji w oparciu o dorobek traktatowy orzecznictwa i doktryny przynależne jest temu podmiotowi, którego lud/naród wykazuje różnice językowe, historyczne, religijne, poczucie wspólnotowości, odmienności i wyjątkowości. Secesja może być także usprawiedliwiona wówczas, gdy lud/naród nie ma warunków do realizowania się w ramach status quo. Nadto lud/naród musi mieć przekonanie o braku możliwości samorealizacji, czemu zwykle towarzyszy łamanie praw i dyskryminujace traktowanie. Kolejnym, bardzo istotnym wymogiem, usprawiedliwiajacym secesję ludu/narodu jest uznanie go w kategorii statusu państwa na forum międzynarodowym ${ }^{7}$. W zasadzie, gdyby poprzestać tylko i wyłącznie na wymienionych przypadłościach, to można by bez żadnych wątpliwości uznać secesję Kosowa za legitymizowaną z pełnym uzasadnieniem. Dla legalności i uznania międzynarodowego wystarczy, że tylko dwa pierwsze, wymienione wcześniej, warunki zostaną spełnione. Wydaje się, że państwa, które już uznały państwowość Kosowa, zasugerowały się prezentowanymi argumentami ${ }^{8}$. Jednak

${ }^{6}$ R. Kownacki, Prawo Kosowa do samostanowienia: $w$ oczekiwaniu na opinię doradcza MTS, „Polski Przegląd Dyplomatyczny” 2010, nr 1 (53), s. 91.

${ }^{7}$ Zob. też J. Crawford, The Creation of States in International Law, Oxford 2006, s. 411-412; por. R. Kownacki, op. cit., s. 96.

${ }^{8}$ Ibidem. 
w opinii autorki jest to tylko jeden $\mathrm{z}$ aspektów uznawalności „oderwanej” prowincji, czym w tym konkretnym przypadku jest pokraina. Przypadek Kosowa utwierdza w przekonaniu, że ograniczenie się tylko i wyłącznie do jednostronnego postrzegania zakłóca wiarygodność i zasadność legitymizacji państwa. Przypomnijmy, że kontrola nad terytorium Kosowa została odebrana siłom serbskim przez interwencję NATO ${ }^{9}$. Rezolucja Rady Bezpieczeństwa Narodów Zjednoczonych nr 1244 z 10 czerwca 1999 r. sprecyzowała status międzynarodowy Kosowa, jednocześnie ustanawiając tam administrację pod auspicjami ONZ ${ }^{10}$. Odtąd Kosowo było zarządzane przez Misję Tymczasowej Administracji Narodów Zjednoczonych (UNMIK), wespół z rodzimymi władzami prowincji11. Rząd Republiki Serbii, nie mogąc pogodzić się z wyodrębnieniem się Kosowa, posługuje się bardzo istotnym argumentem, jakim jest poszanowanie integralności terytorialnej Jugosławii (czytaj: Serbii od 2006 r.) i pozostałych państw regionu. W kontekście prowadzonych rozważań należy zwrócić uwagę na poszanowanie prawa wewnętrznego Republiki Serbii, w tym szczególnie jej Konstytucji z 10 listopada 2006 r. ${ }^{12}$

${ }^{9}$ Interwencja NATO dokonana została pod kryptonimem „Sojusznicza Siła” (,Allied Force”).

${ }^{10} \mathrm{~S} / \mathrm{RES} / 1244$ (1999). W ustaleniu nowego statusu Kosowa w oparciu o rezolucję $\mathrm{nr} 1244$ miano uwzględniać zaakceptowane przez rząd jugosłowiański (zgodnie z prawem międzynarodowym Serbia jest uznana za sukcesorkę Jugosławii) decyzje, które zapadły na spotkaniach szefów dyplomacji G-8 6 maja 1999 r. Nadto brane powinny być pod uwagę zasady rozwiązania problemu kosowskiego, wyrażone przez Radę Bezpieczeństwa ONZ.

${ }^{11}$ Natomiast nad bezpieczeństwem pieczę roztoczyła natowska misja KFOR.

${ }^{12}$ Szerzej na ten temat E. Bujwid-Kurek, Serbia $w$ nowej przestrzeni ustrojowej. Dzieje, ustrój, konstytucja, Kraków 2012, s. 81, 104. Zob. też: eadem, Zasady ustrojowe w zapisie konstytucji Republiki Serbii z 10 listopada 2006 roku, „Atheneum. Polskie Studia Politologiczne” 2011, vol. 32, 
Zarówno preambuła, jak i liczne artykuły tej Konstytucji wyraźnie świadczą o tym, że ogłoszenie jednostronnego aktu niepodległości przez Kosowo było jej złamaniem. Wypracowania konsensusu między stroną serbską i kosowską w tej spornej kwestii oczekiwano w oparciu o propozycję specjalnego wysłannika sekretarza generalnego ONZ Marttiego Ahtisaariego. Przypomnijmy, że skierowana 2 lutego 2007 r. do zainteresowanych stron przewidywała utworzenie na terytorium Kosowa quasi-państwa ${ }^{13}$. Wówczas propozycja ta została zaakceptowana przez Kosowo, które bynajmniej nie przystało na dalsze działania, zmierzające $\mathrm{w}$ kierunku osiagnięcia celu, jakim było całkowite oderwanie się od Serbii i uzyskanie niepodległości.

Bardzo aktywnie w starania o nieuznanie jednostronnego aktu niepodległości Kosowa włączyła się Serbska Cerkiew Prawosławna (SPC). W jednym ze swych oświadczeń, pochodzących jeszcze z 8 lutego 2008 r., wyraziła następującą opinię: Kosowo musi pozostać integralna częścia Serbii, otrzymujac $w$ zamian jak największa wewnętrzna autonomię. Każde inne rozwiązanie, zdaniem wyższych przedstawicieli SPC, jest naruszeniem Karty Narodów Zjednoczonych oraz rezolucji Rady Bezpieczeństwa ONZ nr 1244 z 1999 r., które uznaja terytorium Serbii za serbskie. W opinii autorów tego oświadczenia, przyznanie niepodległości Kosowu spowodowałoby usankcjonowanie skutków wielowiekowej pomocy otomańskiej oraz byłoby potwierdzeniem rozwiazania kwestii kosowskiej, jakie zastosowali faszystowscy okupanci w trakcie II wojny światowej ${ }^{14}$.

s. 93-115; eadem, Stosunki serbsko-kosowskie w latach 2008-2012. Czy zagrożenie dla bezpieczeństwa państw batkańskich?, „Wschodnioznawstwo” 2012, s. 77-91.

${ }^{13}$ Propozycję tę zaakceptowała zdecydowana większość państw UE i USA.

${ }^{14}$ Patrz: Saopštenije za javnost o Kosovu i Metohiji, http://www.spc.rs/ sr (dostęp 17 II 2013). Zob. też M. Seroka, Serbska Cerkiew Prawostawna 
Patriarchowie SPC bardzo często zwracali uwagę na historyczny fakt, że Kosowo stanowi centrum serbskiej tożsamości duchowej, kulturowej $i$ narodowej ${ }^{15}$. Biskupi Cerkwi prawosławnej wyrażali podziękowanie braterskiej Rosji $i$ przyjaciołom $z \operatorname{Chin}^{16}$ za udzielone Serbii wsparcie w nieuznawaniu nowego statusu Kosowa. Poglądy patriarchów SPC konsekwentnie zwracały uwagę na to, że sprawa Kosowa winna być rozwiazana $w$ sprawiedliwy sposób $z$ poszanowaniem zasad prawa międzynarodowego, a przede wszystkim zasady nienaruszalności granic ${ }^{17}$. Znane jest także stanowisko SPC, wyrażone przez metropolitę Amfilohije, że Serbia może wejść do Unii Europejskiej tylko jako całe państwo, to jest $z$ Kosowem jako swoja prowincja ${ }^{18}$.

wobec konfliktów narodowościowych w byłej Jugosławii, [w:] My już jesteśmy zjedzeni... Rola i znaczenie prawostawia $w$ konflikcie etnicznym $w$ Dolinie Preszewa, pod red. R. Zenderowskiego, Warszawa 2012, s. 264.

${ }^{15}$ Znane są częste odwoływania się do mitu bitwy na Kosowym Polu (28 czerwca 1389 r., w kalendarzu juliańskim - 15 czerwca). Od 1892 r. dzień ten uznany został oficjalnie przez SPC za święto kościelne zwane Vidovdan, które, począwszy od lat 80. XX w., przybierało coraz to bardziej na znaczeniu. Miejsce to często synonimicznie zwane jest „Serbską Golgotą, zob.: R. Zenderowski, Religia, etnonacjonalizm i tożsamość narodowa: powiazania i modele relacji (ujęcie teoretyczne), [w:] My już jesteśmy zjedzeni..., s. 103; M. Seroka, op. cit., s. 264. Na temat mitu kosowskiego zob.: R. Zenderowski, Rola i znaczenie prawostawia $w$ ksztaltowaniu serbskiej świadomości narodowej, [w:] My już jesteśmy zjedzeni..., s. 137-139, 184-184.

${ }^{16}$ Zob.: Saopštenije za jaunost Arhijereja...; M. Seroka, op. cit.

${ }^{17} \mathrm{~W}$ tej sprawie odbyło się spotkanie u Patriarchy Rusi z szefem dyplomacji rosyjskiej Siergiejem Ławrowem, Pronaći zdrado rešenje za Kosovo i Metohiju; Vladika Amfilohije razgovarao sa Srgejom Lavrovim, http:// www.src/rs/old (dostęp 5 III 2013). Patrz też M. Seroka, op. cit., s. 267.

${ }^{18}$ Stanowisko takie utrzymywało się nawet po śmierci patriarchy Pavle (styczeń 2010 r.), kiedy jego miejsce zają biskup Niša Irinej, Metropolit Amfilohije: Kosovo je naš Sveti grad Jerusalim; Apel vladike Artimije, http://www.spc.rs (dostęp 5 III 2012). Patrz też M. Seroka, op. cit., s. 268. 
Zanim jednak nastapiła akceptacja samodzielnego Kosowa (bądź też jej brak) w oparciu o orzecznictwo, wyrażone przez predestynowany po temu, kompetentny organ w postaci MTS, czy też ONZ, zostały przedstawione stanowiska przez rządy pojedynczych państw. Jedne uczyniły to w formie oświadczeń pisemnych ${ }^{19}$, inne zaś ustnie ${ }^{20}$. Wśród państw, angażujących się w przedmiotową sprawę, były i takie, które ogłosiły swoje stanowisko w obu formach, np. Serbia, Albania, Niemcy, Wielka Brytania itd. ${ }^{21}$

Wedle opinii Międzynarodowego Trybunału Sprawiedliwości w Hadze deklaracja niepodległości Kosowa nie stanowi naruszenia prawa międzynarodowego. Nie zawiera ono bowiem zakazu ogtoszenia deklaracji niepodległości $i^{22}$.

${ }^{19}$ Oświadczenia w formie pisemnej przedstawione zostały MTS do dnia 17 kwietnia 2009 r. i zostały udostępnione pozostałym członkom biorącym udział w postępowaniu. 36 państw złożyło stosowne oświadczenie pisemne, wśród nich znalazły się takie państwa, jak: Czechy, Francja, Cypr, Chiny, Szwajcaria, Rumunia, Albania, Austria, Egipt, Niemcy, Słowacja, Rosja, Finlandia, Polska, Luksemburg, Libia, Zjednoczone Królestwo Wielkiej Brytanii i Irlandii Północnej, USA, Serbia, Hiszpania, Iran, Estonia, Norwegia, Holandia, Słowenia, Łotwa, Japonia, Brazylia, Irlandia, Dania, Argentyna, Azerbejdżan, Malediwy, Sierra Leone, Boliwia i Wenezuela, R. Kownacki, op. cit., s. 100.

${ }^{20}$ Stanowiska w trybie publicznej prezentacji zostały wyrażone w haskim Pałacu Pokoju podczas publicznych przesłuchań, które odbywały się w dniach 1-11 grudnia 2009 r. Wśród nich znalazły się takie państwa, jak: Serbia, Albania, Niemcy, Arabia Saudyjska, Argentyna, Austria, Azerbejdżan, Białoruś, Boliwia, Brazylia, Bułgaria, Burundi, Chiny, Cypr, Chorwacja, Dania, Hiszpania, USA, Rosja, Finlandia, Francja, Jordania, Norwegia, Holandia, Rumunia, Zjednoczone Królestwo Wielkiej Brytanii i Irlandii Północnej. Niektóre z państw wcześniej zdeklarowanych w ostatniej chwili zrezygnowały z ustnego wyrażenia opinii, są to: Bahrajn i Laos, zob. ibidem, s. 101.

${ }^{21}$ Por. przypisy 19 i 20.

${ }^{22}$ Decyzja MTS w Hadze, pomimo że nie jest obowiązująca, to jednak może być powodem do uznawania dążeń separatystycznych mających 
Jednak, co z całą moca warto podkreślić, wyrażona opinia nie wpłynęła ani na zmianę stanowiska pełnej akceptacji niepodległości Kosowa przez USA, ani też na niechętny stosunek, wyrażany przez Rosję. Sekretarz generalny NATO, Anders Fogh Rasmussen, stwierdził, że stanowisko MTS w Hadze w sprawie Kosowa nie spowodowało reorientacji co do mandatu sił międzynarodowych KFOR, zatem NATO będzie kontynuować swoją misję na obszarze Kosowa ${ }^{23}$. Stanowisko MTS w Hadze nie zdołało zmienić opinii rosyjskiego Ministerstwa Spraw Zagranicznych, które przekonywało, że rozwiazanie problemu kosowskiego jest możliwe jedynie droga kontynuowania rozmów zainteresowanych stron ${ }^{24}$. To właśnie rząd serbski, żywo zainteresowany wyrażeniem stanowiska w spornej kwestii Kosowa, skierował wniosek w tej sprawie do Zgromadzenia Ogólnego ONZ. Przypomnijmy, że 8 października 2008 r. poparło go ono względną większościa głosów. Dotyczył on opinii MTS w sprawie legalności ogłoszenia niepodległości przez Kosowo ${ }^{25}$. Broniąca swego

miejsce na całym świecie. Patrz Trybunat w Hadze zdecydowat: niepodległość Kosowa jest legalna, http://www.wprost.pl/ar/203084/Trybunal-w-Hadze-zdecydowal-niepodleglosc-Kosowa-jest-legalna/ (dostęp 8 III 2013).

${ }^{23}$ Siły pozostające pod nadzorem NATO będą kontynuować swój mandat w celu utrzymania bezpieczeństwa w Kosowie i jego otoczeniu. Siły KFOR stacjonujące w Kosowie liczą około 10 tys. funkcjonariuszy, zob. ibidem.

${ }^{24}$ Jednocześnie należy zwrócić uwagę, że rosyjskie Ministerstwo Spraw Zagranicznych dostrzega zaniedbanie ze strony MTS w Hadze, który wedle ich opinii wziął pod uwagę jedynie deklarację niepodległości pomijając szerszą analizę kwestii prawa Kosowa do jednostronnego odseparowania się od Serbii, zob. ibidem.

${ }^{25}$ Serbski wniosek poparty został przez 77 państw, w tym: Rosję, Brazylię, Indie, Chiny, Argentynę, Indonezję, Hiszpanię, Grecję, Egipt. Sześć państw było przeciwnego zdania, w tym: USA, Albania. 74 państwa wstrzymały się od głosu, natomiast 35 nie uczestniczyło w głosowaniu. Zdecydowana większość państw, które uznały niepodległość Kosowa (w momencie 
stanowiska strona kosowska przekonywała, że deklaracja niepodległości w żadnym razie nie pozostaje w sprzeczności $\mathrm{z}$ rezolucją nr 1244, bowiem nie wyklucza ona w sposób jednoznaczny rozstrzygnięcia statusu Kosowa, uznajac go za samodzielny podmiot prawa międzynarodowego (czytaj: samodzielne państwo).

Jak już wspomniano, na jednostronne ogłoszenie przez Kosowo aktu niepodległości zareagował niemal natychmiast rząd Republiki Serbii. Dušan Bataković ${ }^{26}$ - serbski ambasador występujący przed Trybunałem w Hadze, wespół ze wspierajacymi jego stanowisko Andreasem Zimmermannem, Malcolmem Shawem i Robertem Jenningsem udowadniali nielegalność deklaracji niepodległości Kosowa. Twierdzili, że jednostronny akt samodzielności Kosowa stanowi zagrożenie dla międzynarodowego porządku prawnego, opartego na jednoczesnym poszanowaniu zasad suwerenności i integralności terytorialnej. Szczególnie precyzyjny w swej argumentacji był A. Zimmermann, który w pięciu punktach eksplikował powód swojego stanowiska ${ }^{27}$.

głosowania było ich 48), nie wzięła udziału w głosowaniu bądź wstrzymała się od głosu. Zob. Sukces Serbii w Zgromadzeniu Ogólnym ONZ, http:// www.osw.waw.pl/pl/publikacje/best/2008-10-16/sukces-serbii-w-zgromadzeniu (dostęp 8 VIII 2013).

${ }^{26}$ Przewodniczacy delegacji serbskiej.

${ }^{27}$ Jak pisze Rafał Kownacki, prof. A. Zimmermann wskazywał na sprzeczności między jednostronną deklaracją niepodległości Kosowa a rezolucją nr 1244: 1. Rezolucja nr 1244 potwierdza prymat integralności terytorialnej Jugostawii, a zatem w sposób oczywisty wyklucza jednostronnie proklamowana secesję. 2. Rezolucja nr 1244 ustanowiła określony międzynarodowy reżim prawny, który nie może zostać zniesiony przez jednostronne działania. 3. Jednostronna deklaracja niepodległości nie może być utożsamiana z końcowym rozstrzygnięciem (final settlement), o którym wspomina rezolucja 1244. 4. Jednostronna deklaracja niepodległości narusza kompetencje Rady Bezpieczeństwa, w które wyposażyta ja Karta Narodów 
Prócz Serbii, która, kierowana najbardziej oczywistymi względami, nie wyraziła zgody na samodzielność Kosowa, także Hiszpania bardzo poważnie obawiała się, że takie wydzielenie się ze struktury Republiki Serbii jej pokrainy może rodzić skutki negatywne, zwłaszcza dla państw, w ramach których znajdują się mniejszości narodowościowe. Politycy hiszpańscy stwierdzali, że będzie to stanowić precedens dla separatystycznych tendencji, z aktywnym udziałem zwartych enklaw narodowościowych. W przypadku Hiszpanii moga to być np. Baskowie czy Katalończycy, którzy, jak się wydaje, tylko czekają na sprzyjający temu, korzystny dla artykulacji partykularnych interesów (czytaj: narodowościowych) klimat polityczny. Rząd Królestwa Hiszpanii nie zgadza się $\mathrm{z}$ jednostronnym aktem niepodległości Kosowa, uważając go za niezgodny z prawem międzynarodowym. W wypowiedzi z 20 lutego 2008 r. minister spraw zagranicznych Hiszpanii, Miguel Ángel Moratinos, w obawie przed żądaniami separatystycznymi Basków i Katalończyków, powołując się na prawo do samostanowienia ${ }^{28}$, stwierdził, że jest skłonny do uznania samodzielności, lecz pod warunkiem spełnienia dwóch ważnych, twardych warunków: wpierw kwestia Kosowa powinna być rozstrzygnięta poprzez wypracowanie konsensusu przez rząd Republiki Serbii i władze w Prisztinie, a następnie należy nadać temu formę rezolucji Rady Bezpieczeństwa ONZ, wiążącej obie zainteresowane strony.

Zjednoczonych. 5. Neutralne stanowisko sekretarza generalnego ONZ ws. Deklaracji niepodległości Kosowa nie może być traktowane jako forma uznania, zob. R. Kownacki, op. cit., s. 101-102.

${ }^{28}$ Prawo do samostanowienia okazuje się być zbyt mało czytelna zasadą moralną. Woodrow Wilson sądził, że pozwoli ono rozwiązać problemy Europy Środkowej w 1919 r., ale okazało się, że doprowadziło to do większej ilości sporów, patrz J.S. Nye, op. cit., s. 238. 
Słowacja - to kolejne państwo, które nie uznało jednostronnego aktu samodzielności Kosowa. Gdyby pytać o przyczyny, leżące u podstaw takiej decyzji, to odpowiedź wydaje się być prosta - obawa przed analogicznymi dążeniami separatystycznymi mniejszości węgierskiej. Niemal z tych samych powodów rząd Rumunii wyraził zdecydowany sprzeciw i nie zgodził się z samodzielnością Kosowa. Z wypowiedzi prezydenta Cypru - Dimitrisa Christofiasa - wnioskować można, że jego kraj jeszcze przez długi czas nie będzie skłonny uznać niepodległości Kosowa. Przypomnijmy, że Cypr, wciąż podzielony na część grecką i turecka, z różnym natężeniem doświadcza artykułowanych aspiracji separatystycznych ze strony Tureckiej Republiki Północnego Cypru ${ }^{29}$. Tak więc, odwołując się do analogicznych problemów i zasad, minister obrony Cypru, Costas Papakostas, wyraził opinię, że jego kraj nigdy nie uzna niepodległości Kosowa ${ }^{30}$. W oświadczeniu rzecznika prasowego Ministerstwa Spraw Zagranicznych Grecji, Georgiosa Koumoutsakosa, z 29 sierpnia 2008 r. została wyrażona jednoznacznie profilowana, niechętna opinia w spornej kwestii Kosowa. Zwrócił on uwage na konieczność poszanowania integralności terytorialnej państw, jednocześnie odwołując się do chlubnych tradycji dyplomatycznych wszystkich rządów w tym względzie. Tę sojuszniczą przychylność, wyrażoną dla Serbii, można tłumaczyć przede wszystkim faktem historycznych zażyłości tych dwóch państw.

Z krajów pozaeuropejskich „eurosceptykami” okazały się być: Federacja Rosyjska i Chińska Republika Ludowa. Oba te państwa, będąc stałymi członkami Rady Bezpieczeństwa ONZ, zgodnie wystapiły $\mathrm{w}$ obronie prymatu integralności

${ }^{29}$ Republika ta jest uznawana wyłącznie przez naczelne władze Turcji.

${ }^{30}$ Depesza Radia Serbskiego z 16 czerwca 2009 r.; patrz też R. Kownacki, op. cit., s. 108. 
terytorialnej Republiki Serbii. Rząd Chin byłby skłonny przychylić się tylko do konsensusu, wypracowanego przez zainteresowane strony (Serbię i Kosowo). Jednym z powodów, dla którego Chińska Republika Ludowa pozostaje niechętna wobec samodzielności Kosowa, jest wciąż jeszcze sporna kwestia Tajwanu. Idea ,jednych Chin” wystarczająco usprawiedliwia niechętne stanowisko wobec jednostronnego aktu samodzielności ogłoszonego przez Kosowo ${ }^{31}$.

Federacja Rosyjska, zmagająca się na swoim terytorium z multietnicznościa, która szczególnie dotkliwie daje o sobie znać na obszarze Kaukazu, nie wyraża akceptacji dla samodzielnego bytu państwa Kosowo. W kontekście uznania w 2008 r. przez Rosję niepodległości Abchazji i Osetii Południowej, „oderwanych” od Gruzji, stanowisko, wyrażone wobec jednostronnego aktu niepodległości Kosowa, stało się mało wiarygodne, zwłaszcza przed MTS. Można zauważyć, iż zasada nadrzędności poszanowania integralności terytorialnej nad prawem do samostanowienia bynajmniej nie jest niepodważalną zasadą rosyjskiej polityki zagranicznej. Jednakże mimo to rząd rosyjski szczególnie zwracał uwagę na fakt, że nieprzemyślana decyzja krajów, zaliczanych do wcale niemałego grona „eurooptymistów” (określenie autorki) w kwestii Kosowa, wywoła negatywne zjawiska w państwach, które stan ten zaakceptowały, choć nie sa one zupełnie wolne od podobnych zjawisk na swoich terytoriach ${ }^{32}$.

${ }^{31}$ Dostrzega się tu obustronne poparcie (czytaj: serbsko-chińskie) w kwestii integralności terytorialnej głoszonej przez dwie strony. Por. wypowiedź szefa rządu Republiki Serbii, Božidara Delicia, z 7 kwietnia 2009 r., cytowaną w depeszy agencji Tanjug.

${ }^{32}$ Co do tak wyrażonej opinii zgodni byli zarówno Władimir Putin, jak i Dmitrij Miedwiediew. Stojąc na stanowisku poszanowania zasady integralności terytorialnej Serbii, byli oni zdania, że kwestia Kosowa winna być rozstrzygnięta w oparciu o rezolucję Rady Bezpieczeństwa ONZ nr 1244. 
Grono niechętnych statusowi samodzielnej Republiki Kosowa wyróżnia się zasadniczą cechą: wszystkie te państwa zmagaja się z niełatwymi tendencjami separatystycznymi, artykułowanymi przez narodowości/mniejszości narodowe, które zamieszkują ich terytoria. Precedens Kosowa może być dobrym alibi dla mniejszości węgierskiej (w Słowacji i Rumunii), dla Katalończyków i Basków ${ }^{33}$ w Hiszpanii, czy też dla ludności tureckiej, zamieszkującej północną część Cypru. Tylko Republika Serbii jest w zupełnie innej sytuacji, gdyż Kosowo, historycznie rzecz biorąc niemal „od zawsze”, było kolebką serbskości, obszarem traktowanym za swego rodzaju sacrum (świętość) serbskości i narodu serbskiego. Kosowo, stanowiące szczególną ikonę dla Republiki Serbii, widniejące w zapisie jej konstytucji, postrzegane jest tu na zupełnie innych, bo wyjątkowych zasadach.

\section{$* * *$}

Jak już wcześniej wspomniano, do tzw. kosowskich entuzjastów spośród najbardziej znaczących państw na świecie zalicza się USA, a z grona państw Unii Europejskiej - Niemcy, Francję, Wielką Brytanię i Polskę, która jako dziesiąty w kolejności kraj na świecie uznała samodzielność Kosowa ${ }^{34}$. Rząd Stanów Zjednoczonych od samego niemal początku był entuzjastą tej niepodległości. W przekonaniu wiceprezydenta USA, Joe Bidena, wizytującego Kosowo blisko rok po „uczynieniu się" przez nie niepodległym państwem (21-22 maja 2009 r.), niezawisłe Kosowo stanowi jeden z najważniejszych

${ }^{33}$ Więcej na ten temat zob. H. Szymańska, Problem baskijskii, [w:] Spory i konflikty międzynarodowe..., s. 162-191.

${ }^{34}$ Stało się to 26 lutego $2008 \mathrm{r}$. W tej sprawie została przyjęta uchwała Rady Ministrów nr 38/2008 ws. uznania przez Rzeczpospolitą Polską Republiki Kosowa. Por. R. Kownacki, op. cit., s. 108. 
elementów długookresowej stabilizacji i pokoju na obszarze Bałkanów Zachodnich. Co więcej, ogłoszenie tej niepodległości oficjalnie uznane zostało przez Bidena za jedyne rozsądne rozwiązanie i w związku z tym nie może być odwołane $^{35}$. Z jednej strony szybkie uznanie przez USA niepodległości Kosowa może zdumiewać, a to zważywszy szczególnie na złamanie prawa wewnętrznego (czytaj: nadrzędnego aktu prawnego) Republiki Serbii, z drugiej jednak można się było tego spodziewać. Przypomnijmy, że amerykańscy i europejscy dyplomaci uważnie obserwowali pogarszająca się sytuację w Kosowie jeszcze w czasie trwania otwartego konfliktu zbrojnego na tym obszarze - pod katem naruszenia praw człowieka. Jasne było, że administracja ówczesnego prezydenta USA, Billa Clintona, nie zgodzi się na to, by Kosowo stało się kolejną Bośnia, gdzie ofiarami masakr zostały tysiące Muzułmanów. Po tym, jak zawiodły negocjacje oraz sankcje gospodarcze wobec Serbii, Stany Zjednoczone i Pakt Północnoatlantycki rozpoczęły wiosną 1999 r., trwające 78 dni, naloty na to państwo. Odpowiedzią było wycofanie z Kosowa w czerwcu tego samego roku przez Slobodana Miloševicia wojsk serbskich. W ich miejsce NATO rozmieściło międzynarodowe siły stabilizacyjne. W kontekście prowadzonych rozważań zauważyć trzeba, iż mimo tego, że udało się powstrzymać mordy, porozumienie, dotyczące „ostatecznego statusu” Kosowa, wciąż pozostawało wtedy jeszcze sprawą otwarta $^{36}$. W opinii ówczesnego szefa dyplomacji Francji, Bernarda Kouchnera, deklaracja niepodległości Kosowa była działaniem w imię dobrze pojętego „wspólnego dobra”. Wedle tego polityka była także dobrym powodem do wypracowania ewentualnego konsensusu serbsko-kosowskiego, który

${ }^{35} \mathrm{http} / / /$ pristina.usembassy.gov (dostęp 21 VI 2009).

${ }^{36}$ J.S. Nye, op. cit., s. 238. 
niebawem zostanie wymuszony na obu stronach przez wspólne ich członkostwo w Unii Europejskiej ${ }^{37}$.

Z nieskrywanym zadowoleniem, uznaniem i atencja wypowiadał się w sprawie nas interesującej ówczesny brytyjski minister spraw zagranicznych - Gordon Brown. Ogłoszona samodzielność Kosowa uznał on za ważny moment, w którym nastapiło ostateczne zamknięcie jednego z istotnych etapów w dziejach regionu bałkańskiego. W akceptacji niepodległości Kosowa nie pomijał wymogu formalnego, jakim była gwarancja władz Kosowa dla przestrzegania praw tamtejszej mniejszości serbskiej. W komunikacie Kancelarii Premiera Wielkiej Brytanii z 18 lutego 2008 r. czytamy, że tylko dzięki istnieniu dwóch niezależnych podmiotów państwowych możliwe będzie osiagnięcie przez zarówno Serbię, jak i Kosowo petnej integracji z Unia Europejska.

Rząd niemiecki także jako jeden z pierwszych wyraził niemal pełną akceptację dla niepodległości i samodzielnego bytu państwowego Kosowa. Zostało to wyrażone w bardzo szybko wysuniętej propozycji nawiązania stosunków dyplomatycznych. Formalnym aktem uznania nowego państwa przez rząd RFN było pismo, które do przywódcy Kosowa - Fatmira Sejdiu - wystosował ówczesny prezydent Niemiec - Horst Köhler ${ }^{38}$. Ma to swoje konsekwencje dla relacji niemiecko-serbskich, zwłaszcza w procesie stowarzyszenia Serbii z Unią Europejska. Wśród siedmiu warunków, stawianych przez rządzącą w Niemczech koalicję CDU/CSU, którym Serbia powinna sprostać, znalazły się aż cztery w kwestii Kosowa. I tak, oczekuje się realizacji

${ }^{37}$ Bernard Kouchner posiadał ścisłe związki z Kosowem - pełnił tam funkcję pierwszego specjalnego wysłannika sekretarza generalnego ONZ. Wspierał Kosowo w jego staraniach przed Międzynarodowym Trybunałem Sprawiedliwości w Hadze.

${ }^{38}$ http://www.zw.eom.pl/artykul/222793.html (dostęp 17 III 2013). 
dotychczasowych porozumień $w$ dialogu $z$ Prisztina oraz kontynuacji tego dialogu, a także inicjatywy w kwestiach nieprzewidzianych dotychczas $w$ umowach, np. energetyki $i$ telekomunikacji $i^{39}$. Jednym z warunków jest zobowiązanie władz Republiki Serbii, by ludność serbska, zamieszkująca północną czesść Kosowa, była bardziej aktywna we współpracy z misjami pokojowymi tam stacjonującymi: EULEX i KFOR. Kolejnym jest wymóg zlikwidowania paralelnych struktur serbskich władz w Kosowie i zakończenie ich finansowania. Niemiecki Bundestag, warunkując członkostwo Serbii w Unii Europejskiej, stoi na stanowisku, że jej władze musza wykazać gotowość do podpisania porozumień normalizujacych stosunki bilateralne $z$ Kosowem, by w przysztości oba państwa członkowskie [czytaj: Serbia i Kosowo - E. B.K.] mogty realizować swoje wspólne $i$ indywidualne interesy. I w tym przypadku stanowisko Serbii w nieuznaniu Kosowa jako samodzielnego państwa jest nieprzejednane. O ile ówcześnie sprawujący funkcje wicepremiera i ministra obrony Republiki Serbii, Aleksandar Vučić, oświadczył, że Serbia nie może uznać niepodległości Kosowa, ale że Niemcy moga oczekiwać, iż wszelkie zobowiazania poprzedniego rzqdu Serbii $w$ dialogu $z$ Prisztina zostana wprowadzone $w \dot{z} y c i e^{40}$, to jednak wicepremier Rasim Ljajić oznajmił¹

\section{${ }^{39}$ Warunek nr 4 stawiany przez CDU/CSU.}

${ }^{40}$ Niemcy stawiaja Serbii kolejne warunki $w$ kwestii członkostwa $w$ UE, http://balkanistyka.org/niemcy-stawiaja-serbii-kolejne-warunki-wkwestii-czlonkostwa-w-ue/ (dostęp 15 X 2012).

${ }^{41}$ Wywiad udzielony telewizji Pink. Rasim Ljajić stwierdził także, że spetnienie warunków o rozwiazaniu problemów telekomunikacyjnych $i$ energetycznych będzie trudne $w$ realizacji $i$ konieczne będa ustęstwa ze strony Serbii. Została nadto zwrócona uwaga na fakt, że Kosowo domaga się niezależnego numeru kierunkowego +383. Nie mogąc go uzyskać, Parlament Kosowa uchwalił ustawę, w której stanowi się o przejściu na prefiks albański o numerze +355 . W takiej sytuacji Serbia zaproponowała 
z siedmiu warunków, jakie strona niemiecka postawiła przed Serbia w sprawie rozpoczęcia negocjacji akcesyjnych do Unii Europejskiej, sa oderwane od rzeczywistości. Za takie uznał szczególnie likwidację paralelnych struktur serbskich władz w Kosowie ${ }^{42}$. Dla Serbii wymogi, stawiane przez Bundestag, sa bardzo trudne do realizacji. Jednak należy zauważyć, że pomimo wielu problemów z tym związanych, politycy serbscy sa w pełni świadomi, iż nie nastapi realny rozwój gospodarczy, jeśli Serbia wyrzeknie się współpracy z Niemcami ${ }^{43}$.

Konkludując, stwierdza się, że różnice zdań, wyrażane zwłaszcza przez najbardziej liczące się państwa na świecie, w kwestii uznania Kosowa za legalne państwo europejskie, moga przez długi jeszcze czas stanowić rdzeń niezgody w toczonych dyskusjach i sporach politycznych. Autorka wyraża obawy nawet daleko bardziej idace, a mianowicie casus Kosowa, uznany dziś za ważną kwestę polityczną Bałkanów Zachodnich, może też przyczynić się do reaktywowania zredefiniowanej „neozimnej” wojny, toczonej pomiędzy państwami zaliczanymi do kosowskich eurooptymistów i kosowskich eurosceptyków. O tym przekonuje wyraźny podtekst polityczny, towarzyszący uznawalności bądź niewyrażaniu zgody na ogłoszenie jednostronnego aktu niepodległości przez

międzynarodowy numer kierunkowy +3815 , który jednoznacznie świadczyć by miał o wspólnocie z Serbią (+381 to numer kierunkowy w połączeniach międzynarodowych z Serbia), jak również wskazywał na niezależność od Serbii (poprzez dodatkową cyfrę 5). Jeśli zaś chodzi o kwestie energetyki, to oznajmił on, że wspólnota międzynarodowa domaga się, by systemy energetyczne Valč i Gazivoda stały się częścią systemu kosowskiego. Podówczas były one wciąż jeszcze własnością serbskiego Skarbu Państwa, ibidem.

${ }^{42}$ Zob. ibidem.

${ }^{43}$ Wicepremier Serbii, A. Vučić, wyraził zadowolenie z podpisanego protokołu o współpracy między niemiecką spółką RWE a firmą Elektroprivreda Srbije, zob. ibidem. 
Kosowo. Pomimo że 19 kwietnia 2013 r. premier Serbii, Ivica Dačić, i premier Kosowa, Hashim Thaçi, doszli do porozumienia w sprawie normalizacji wzajemnych stosunków, co niewątpliwie umożliwi rozpoczęcie negocjacji akcesyjnych Unii Europejskiej z Serbia, to jednak nadinterpretacja premiera Kosowa jest uznanie tego porozumienia za akceptację legalności Republiki Kosowa jako samodzielnego państwa. W opinii autorki, Serbia nie uzna Kosowa, co wcale nie przeszkadza, jak dowodzą fakty, normalizować stosunki między stronami ${ }^{44}$. I, co więcej, bynajmniej nie stanowi to przeszkody ani dla Kosowa, ani dla Serbii do nabycia pełnoprawnego członkostwa w UE.

${ }^{44}$ Proces negocjacji akcesyjnych Belgradu z UE jest uzależniony od normalizacji stosunków między Serbią i Kosowem. Prowadzone od listopada 2012 r. pod auspicjami Unii rozmowy pomiędzy premierami Serbii i Kosowa dotyczyły w znacznej mierze administracji północnej części Kosowa, zamieszkanej przez mniejszość serbska. Na mocy porozumienia zawartego 19 kwietnia 2013 r. serbskie gminy w północnym Kosowie miały utworzyć wspólnotę, która będzie mieć znaczący wpływ na desygnowanie komendanta policji w tym regionie, jednocześnie gwarantując sobie prawo do zgłoszenia kandydata. Wspólnota, mająca siedzibę w Kosovskiej Mitrovicy, ma mieć prawo do własności, własnego konta bankowego, własnych naczelnych organów władzy państwowej (parlament, prezydent, wiceprezydent i rada, czyli rząd), będzie też sprawować funkcję kontrolną nad oświata, kulturą i planowaniem przestrzennym. Nadto porozumienie przewiduje, że Serbia nie będzie blokować w przyszłości integracji Kosowa z Unią Europejska. Wdrażanie porozumienia może odbywać się przy aktywnej pomocy NATO. Sekretarz generalny Sojuszu, Anders Fogh Rasmussen, wyraził zadowolenie, że NATO mogło pomóc w osiagnięciu tego historycznego porozumienia, zob. http://wyborcza.pl/1,91446,13774367,UE_Porozumienie_Serbii_i_Kosowa_ws_no... (dostęp 4 V 2013). 